\title{
WORDS OF WISDOM, WORDS OF WAR: A STUDY OF TERMS AND CONCEPTS IN IV MACCABEES
}

\section{Gerhard Swart}

\author{
Department of Ancient Languages and Cultures \\ University of Pretoria \\ E-mail: gerhard.swart@up.ac.za \\ (Received 09/02/2015; Accepted 01/04/2015)
}

\begin{abstract}
In the words of Jan Willem van Henten (1997:296), the fourth book of Maccabees "presents itself to the reader, from the very beginning of the work, as a philosophical discourse about the dominance of devout reason over the emotions". Despite the fact that the terminology and phraseology employed in this initial portrayal keeps recurring at various points throughout the book, several scholars have noticed a disturbing mismatch between the prologue and the main body of the work. This paper addresses the question whether or not IV Maccabees is structured according to a thematically unified plan, and attempts to find an answer by focusing on some philosophical terms and concepts and the ways in which these feature in the composition as a whole.
\end{abstract}

\section{INTRODUCTION}

The opening lines of the fourth book of Maccabees - stating the author's intention "to

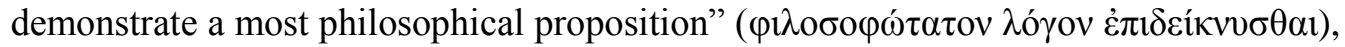
namely, "whether pious reason has sovereign power over the passions" ( $\varepsilon \dot{i}$

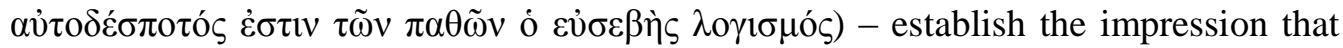
the work is a philosophical treatise. ${ }^{1}$ The immediately following verses (IV Macc 1:212) continue along the same lines, announcing the subject and explaining in general terms how the initial proposition will be illustrated. This section is structured according to the classical rules of rhetoric pertaining to the exordium of a speech

1 The Greek terminology employed in this statement is significant: first, غ̇ $\pi 1 \delta \varepsilon i ́ \kappa v v \sigma \theta \alpha \imath$ categorises the treatise as epideictic in character; and secondly, the semantic content of

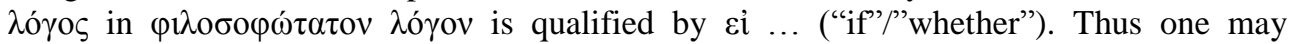
interpret this statement as referring to the "highly philosophical question whether pious reason is master of the passions" (cf. also DeSilva 2013:58: "quintessentially philosophical principle ... if ..."). 
(Klauck 1994:104, quoted in van Henten 1997:69 n.53).

After presenting definitions and a discussion of the relevant concepts, including examples from the history of Israel that illustrate the virtues fostered by pious reason, the introductory section (IV Macc 1:1-3:18) is followed by a martyrology - a narrative about the torture and execution of nine Jewish martyrs: the aged priest Eleazar, a woman (a widow?) and her seven sons, by soldiers of the Seleucid king Antiochus IV. This narrative section comprises the remainder of the work, resulting in IV Maccabees being "the oldest Jewish text that is devoted to martyrdom in its entirety" (van Henten, 1997:58; cf. Anderson, 1985; Young, 1998). The means and mechanisms of torture are described in horrific detail, leaving the reader - this reader, at least - stunned and somewhat perplexed as to what precisely the author intended to communicate by this work.

\section{PROBLEM STATEMENT}

There seems to be general scholarly consensus that the fourth book of Maccabees "presents itself to the reader, from the very beginning of the work, as a philosophical discourse about the dominance of devout reason over the emotions" (van Henten 1997:296). However, despite the fact that the terminology and phraseology utilised for this initial portrayal keeps recurring at various points throughout the book, several scholars have been disturbed by what seems to be a mismatch between the introductory section and the main body of the work. The introductory section or hypothesis (IV Macc 1:1-3:18) creates expectations that are not satisfied by the martyrology commencing at 3:19 and taking up the remainder of the book $(3: 20-$ 18:24), unless one would concede that the narrative containing the martyr stories successfully proves the philosophical thesis (cf. van Henten, 1997:58, 296; Craven, 2014). The question that arises from these observations is whether or not IV Maccabees is structured according to a thematically unified plan. I will attempt to find an answer to this question by focusing on some philosophical terms and concepts that occur and keep recurring in the book, and especially on the ways in which these terms 
and concepts feature in the composition as a whole.

While it could be argued that the martyrology - since it comprises the bulk of IV Maccabees - is the main focus of the book, and that its effect on the reader represents the intended impact of the work as a whole, one cannot ignore the possibility that the mixed nature of this document may be a signal to the reader to look deeper than the surface. Is the aim of IV Maccabees merely to impress its readers by the courage and resolve of the Maccabean martyrs? Or is the work intended to convey a propagandistic political/philosophical message, namely, that the oppressor is vanquished, despite all the military means available to him as king of the Seleucid empire; beaten at his own game (philosophy, the speciality of the Greeks) by a ridiculously unlikely resistance force (nine faithful Jews: an aged priest, a woman and seven mere youths)? This is the hypothesis that the author undertakes to expound in the present paper.

\section{METHODOLOGICAL ISSUES}

The main thrust of my approach towards dealing with these questions and testing this hypothesis is a close reading of the text. By the phrase "close reading" is meant a detailed, sustained interpretation of thematically related sections of the Greek text of IV Maccabees. While paying attention to details at the micro level, a constant tension between this and the macro level features and relations of the text will be observed. This should serve as a control measure, to prevent the reader from isolating terms, phrases, concepts and propositions from their context, by requiring that the interpretation of individual items be constantly verified against the backdrop of the textual web in which they are enmeshed.

Note also that the close reading envisaged here - while paying attention to textual details at both the micro and macro level - does not take everything that is stated in the text at face value. Consider this analogy: Close reading may be like harvesting words and phrases, sorting them according to shared features, labelling the various bundles, and presenting these labels as the reader's interpretation of the text. Several scholars seem to proceed in this fashion with regard to IV Maccabees; they merely 
select philosophical motifs from the text and enumerate these, together with similar motifs from other Hellenistic Jewish texts, as constituting evidence that "the Maccabean martyrs are presented as Jewish philosophers" (van Henten 1997:271) - or even that "the author of 4 Maccabees expounds what can be called a truly distinct Jewish philosophy" (1997:271). While such statements are quite probably true, they are not really enlightening. They merely state the obvious, without penetrating to the problematic features of the text, such as the question of why the author of IV Maccabees would go to such extremes as he did in describing the cruel torturing and execution of the Maccabean martyrs if his primary aim was merely to present these martyrs as exponents of a philosophy that is distinctly Jewish.

In terms of my analogy, the harvest of this almost naïve reading of the text hardly warrants the amount of energy spent while collecting the bits and pieces of evidence to support the rather commonplace conclusions reached. This applies especially to the philosophical terminology in IV Maccabees: if the occurrence of terms such as

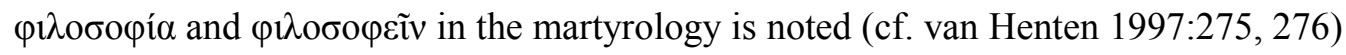
merely to conclude that "the author ... consciously presented the Jewish religion as a philosophy and, as a consequence, individual Jews as philosophers" (1997:276), the knowledge gained is hardly worth the effort involved.

The "close reading" proposed here shifts the focus from collecting ("harvesting") material from the text, toward analysis and interpretation of textual material within its contextual setting. In general terms, this approach brings to light - amongst other observations - that the author does not record "facts" but portrays people interacting with one another; and that the text can be read as a polemical document. More specifically, this means that the Seleucid oppression is portrayed as inherently flawed; that the pretence of a superior philosophy is exposed as false; and that the true philosophy of the Jewish faith is presented as victorious despite the physical defeat and death of its champions.

Regarding the extended dialogue between Antiochus and Eleazar (IV Macc 5), van Henten states: "This conversation is presented by the author as a discussion between two intellectuals" (1997:275). To this he adds: "The two antagonists ... take specific 
philosophical positions" (van Henten, 1997:276). Is this really what happens in the text? In my opinion, a close reading would suggest otherwise.

Having stated these considerations, it is time now to get down to a practical illustration of the type of close reading discussed above.

\section{ANALYSIS}

While scanning the text of IV Maccabees for philosophical terminology, it was found that such terms occur throughout, but are clustered mainly in and around the dialogue between the king and Eleazar (5:4-6:1a). Of the 11 occurrences of terms with the root $\varphi \iota \lambda \circ \sigma \circ \varphi-$, for instance, only three are not within or directly related to that dialogue. Of these three, the first two occur at the very beginning of the book, where the

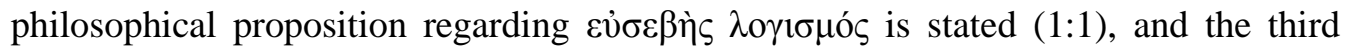
follows immediately after the Eleazar narrative (in 8:1), where the youths are introduced who are about to follow the same path as the aged priest because they

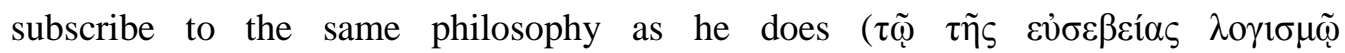

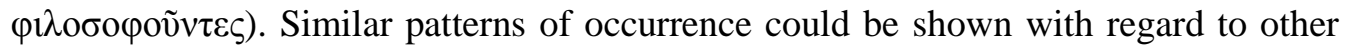
philosophical terms also. A tentative conclusion - one might say, a working hypothesis - to be drawn from these observations, is that the dialogue between Antiochus and Eleazar seems to be the most fertile field and holds the best promise of yielding a bountiful harvest in terms of enhancing our understanding of the philosophical nature of IV Maccabees.

Therefore, a close reading of this dialogue is indicated; but this reading needs to avoid divorcing the dialogue from its literary context. Our interpretation of the dialogue can only be valid to the extent that it takes account of, and is compatible with, the introductory section of the book - to which we will now turn our attention.

\section{Exordium and exposition of the subject (1:1-3:18)}

As a first step towards proving the philosophical proposition that pious reason has dominance over the emotions, the author of IV Maccabees claims that reason (ó $\lambda$ ó $\gamma \circ$ 


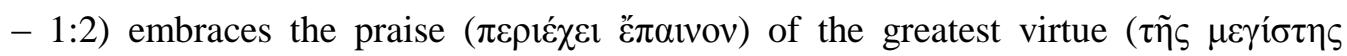
$\dot{\alpha} \rho \varepsilon \tau \tilde{\eta} \varsigma)$, that of prudence ( $\varphi \rho \circ v \eta ́ \sigma \varepsilon \omega \varsigma)$. This virtue is then said to encompass

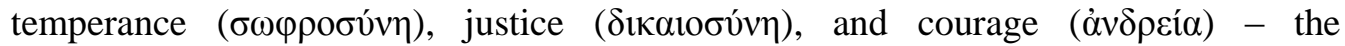
remainder of the so-called cardinal virtues, a foursome initially derived from the framework Plato presented in the Republic, book IV, 426-435. In 1:18-19 these same

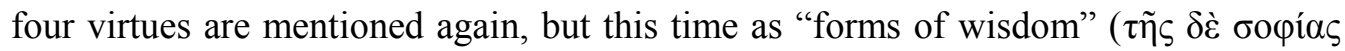
i $\delta \varepsilon \alpha \imath$ ); and again prudence ( $\varphi \rho o ́ v \eta \sigma ı \varsigma)$ is assigned primacy of place among the four -

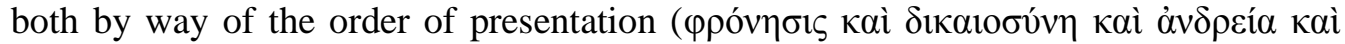

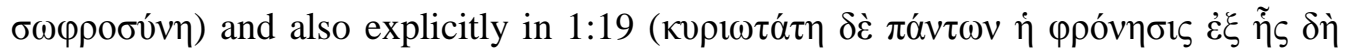
$\tau \tilde{\omega} \nu \pi \alpha \theta \tilde{\omega} \nu$ ó $\lambda o \gamma 1 \sigma \mu o ̀ \varsigma ~ \varepsilon ̇ \pi ı \kappa \rho \alpha \tau \varepsilon \tilde{)}$.

These observations allow us to note that the author consciously - and perhaps deliberately - suggests a connection between Jewish wisdom and Hellenistic philosophy: Both are seriously concerned with virtue; and there are considerable similarities between the sets of virtues valued by both systems. One major difference is not mentioned yet; we will have occasion to consider it in the context of Eleazar's speech in chapter 5. Note, for now, (1) that the author shows no reluctance to assimilate a distinctly Greek value system, even to the point of using the same terms

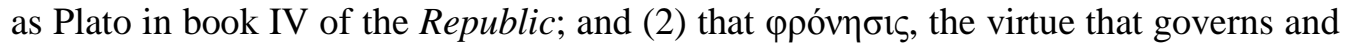
epitomises the others, is said to be the one by whose means reasoning rules the emotions.

When the reader learns that the author intends to demonstrate ( $\dot{\alpha} \pi \circ \delta \varepsilon i \xi \alpha \mu \iota-1: 8)$ the truth of the initial proposition by the courageous conduct ( $\dot{\alpha} \pi$ ò $\tau \tilde{\eta} \varsigma \grave{\alpha} v \delta \rho \alpha \gamma \alpha \theta i \alpha \varsigma$ ) of Eleazar and seven brothers and their mother, who faced death for the sake of virtue

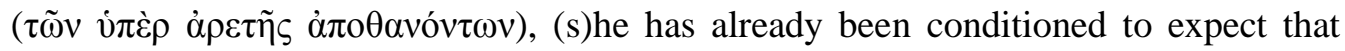
these individuals will be portrayed as examples of temperance ( $\sigma \omega \varphi \rho \circ \sigma v ́ v \eta)$, justice

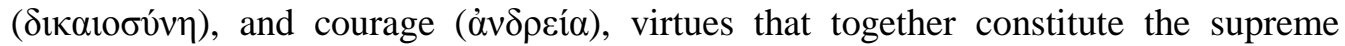

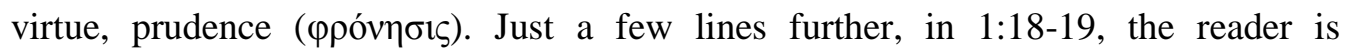
reminded of these same virtues again, and it does not seem to be a problem at all that the virtues represent a Greek value system. ${ }^{2}$

2 This is noted also by David DeSilva (2007:113). DeSilva, however, seems to assume a seamless identification between the author of IV Maccabees and the character of Eleazar. 
If we keep this in mind when reading further, we will be less inclined to take for granted that "[t]he philosophy of the martyrs is contrasted with the Greek philosophy of the king" (van Henten 1997:271); and if we keep the same in mind when turning our attention specifically to the dialogue between Antiochus and Eleazar, we will probably not uncritically accept a statement such as that "[b]oth construct their arguments with care and come to logically consistent standpoints" (1997:275).

\section{Eleazar's story $(5: 4-7: 23)$}

After a brief survey of the Maccabean history and of Antiochus IV Epiphanes' decision to force all the Hebrew inhabitants of Jerusalem to partake in a sacrificial meal that involved eating pork, the author sketches a direct confrontation between the king himself and a senior member of the assembly, the lawyer Eleazar, of a priestly family. The confrontation (5:4-6:1a) is presented in the form of a debate, almost like the agon scenes typical of classical Greek tragedies.

\section{Antiochus' rhetoric:}

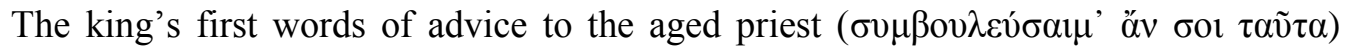
leave no doubt about what is demanded: taste some pork (that is: deny your religion) and save your own life (implying that refusal to obey will result in capital punishment). Ironically, the polite phrase with which the king opens his address to

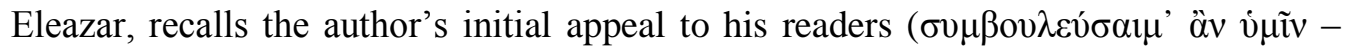
1:1b) to give heed to philosophy. The king's advice is all but polite, however; feigned politeness conceals a stern threat. It does not make much difference that this threat is immediately toned down by a typical captatio benevolentiae: "I feel respect for your age and your grey hair".

With this introduction the king launches a philosophical-rhetorical discourse, carefully structured to achieve the intended effect on Eleazar: 


\begin{tabular}{|c|c|}
\hline 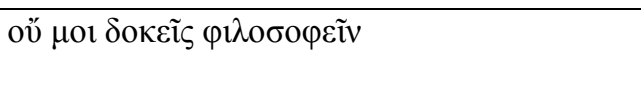 & $\begin{array}{l}\text { You don't seem to me to be practising } \\
\text { philosophy }\end{array}$ \\
\hline 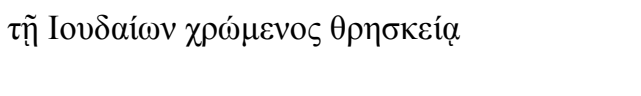 & $\begin{array}{l}\text { when you observe the religious rules of the } \\
\text { Jews. }\end{array}$ \\
\hline 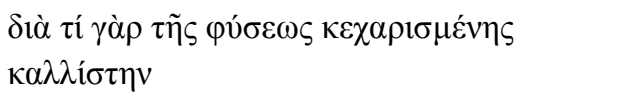 & $\begin{array}{l}\text { Why, when nature has granted you a most } \\
\text { precious gift, }\end{array}$ \\
\hline 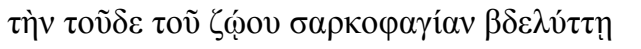 & do you abhor eating the flesh of this animal? \\
\hline 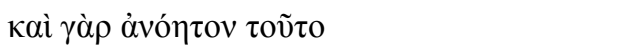 & It is indeed foolish \\
\hline 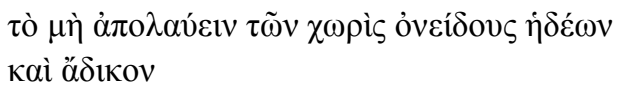 & $\begin{array}{l}\text { not to enjoy pleasures that are blameless; } \\
\text { and it is an offense }\end{array}$ \\
\hline 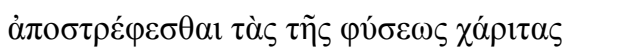 & to reject the gifts of nature. \\
\hline 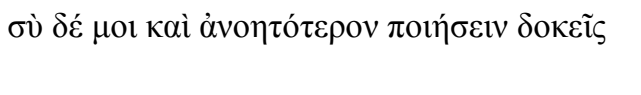 & $\begin{array}{l}\text { Indeed I think you will be doing something } \\
\text { very foolish }\end{array}$ \\
\hline 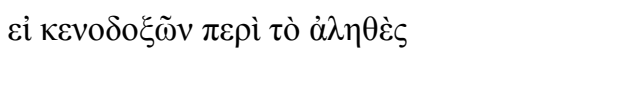 & $\begin{array}{l}\text { if, due to false assumptions about what is } \\
\text { true, }\end{array}$ \\
\hline 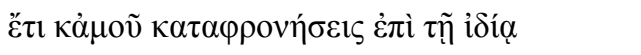 & you will disrespect me - to your own \\
\hline$\tau \iota \mu \omega \rho i ́ \alpha$ & punishment. \\
\hline 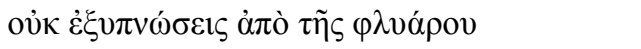 & Won't you wake up from your senseless \\
\hline$\varphi 1 \lambda о \sigma o \varphi i ́ \alpha \varsigma \dot{v} \mu \tilde{\omega} v$ & philosophy \\
\hline 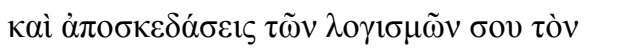 & and rid yourself of the nonsense of your \\
\hline$\lambda \tilde{\eta} \rho \circ$ & reasoning, \\
\hline 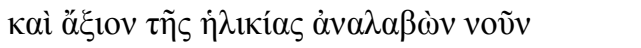 & and, with understanding worthy of your age, \\
\hline$\varphi ı \lambda о \sigma o \varphi \eta ́ \sigma \varepsilon ı \varsigma \tau \eta ̀ \nu ~ \tau o \tilde{~} \sigma v \mu \varphi \varepsilon ́ \rho o v \tau o \varsigma$ & practise the true philosophy of what is \\
\hline$\dot{\alpha} \lambda \eta \dot{\theta} \theta \varepsilon 1 \alpha \nu$ & beneficial? \\
\hline 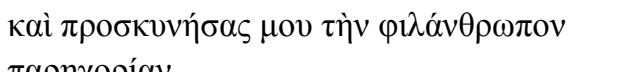 & Won't you, with due respect to my kind \\
\hline$\pi \alpha \rho \eta \gamma о \rho i ́ \alpha \nu$ & advice \\
\hline 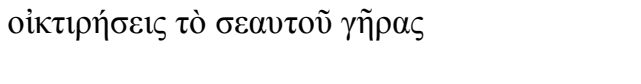 & $\begin{array}{l}\text { have sympathy with your own advanced } \\
\text { years? }\end{array}$ \\
\hline 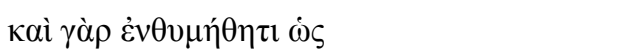 & Indeed you should keep this in mind: \\
\hline 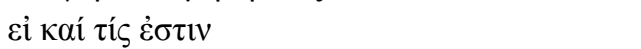 & Even if there is some power \\
\hline 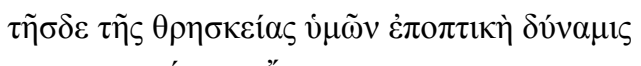 & that watches over this religiousness of yours, \\
\hline 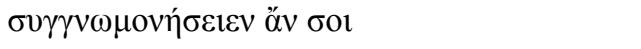 & that (power) would surely pardon you \\
\hline 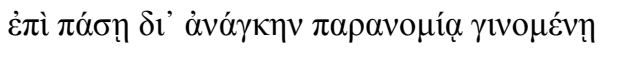 & $\begin{array}{l}\text { for any transgression that may occur due to } \\
\text { necessity? }\end{array}$ \\
\hline
\end{tabular}

3 Or: "exercising philosophical reasoning" (DeSilva 2007:106). 


\section{Running commentary on Antiochus' speech $^{4}$}

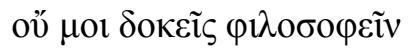

- Note that Eleazar has been introduced as advanced in years, of a priestly family, a leader in the community, trained in the law, and known to many of the king's company - but not as a philosopher. Against that background, we are probably justified in reading this remark as a taunting challenge by the king, prompting Eleazar to enter into a philosophical contest - a battle of wits.

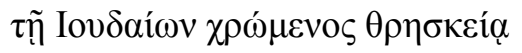

- With "of the Jews" the king isolates Eleazar from his own people - a subtle rhetorical strategy.

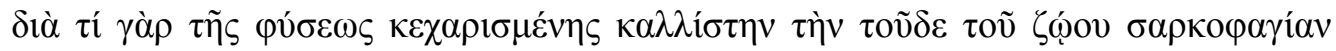

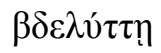

- Ingratitude, or refusing the good gifts of nature, is seen as foolish from an Epicurean perspective. Note the central position of the adjective $\kappa \alpha \lambda \lambda i \sigma \tau \eta v$ : nature's gifts generally, but also the eating of pork specifically, is said to be "the very best".

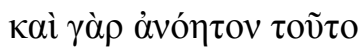

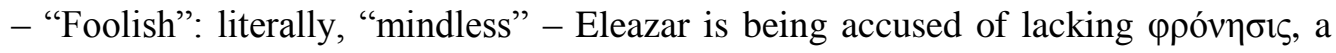
cardinal virtue.

$\tau$

- The Epicurean perspective returns - but by implication, the validity of the Law is denied.

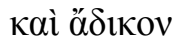

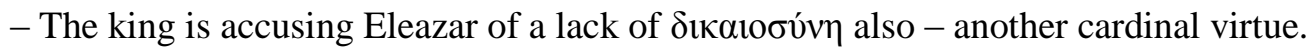

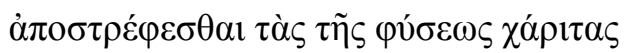

- The king now repeats the accusation of ingratitude; cf. also the author's explanation

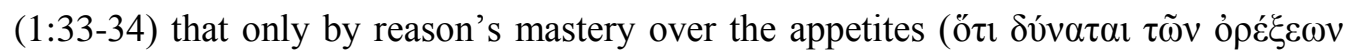

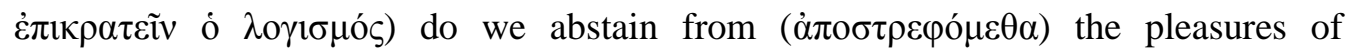

4 Not much use has been made of David DeSilva's Commentary on the Greek text in codex Sinaiticus (2006) for the compilation of these notes. DeSilva's running commentary is aimed more at the discussion of larger textual units than at a detailed analysis of individual words, phrases and clauses - cf. van Henten (2008:399-400). 
forbidden foods, when prompted to, or desiring, these.

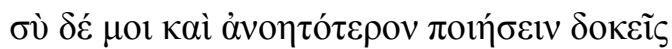

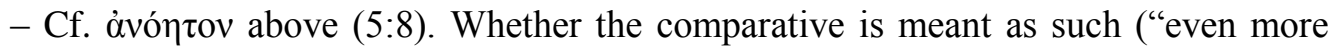
foolish"), or with intensifying force ("very foolish indeed"), the implication is the same: Dishonouring the king is worse than merely lacking the cardinal virtue of prudence.

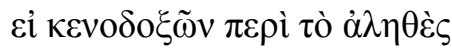

- "False assumptions": literally, "empty notions". We are about to hear what Antiochus regards as true philosophy ...

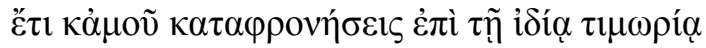

- The threatening tone returns: Eleazar will be punished if he treats the king with contempt.

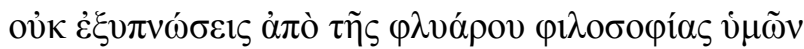

- Again the king fakes politeness: "Won't you ...?" expresses a tone more suitable to a subordinate person addressing a king.

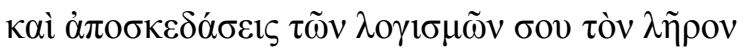

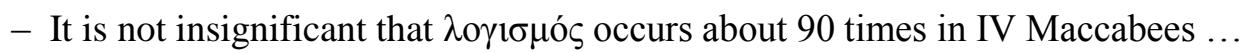

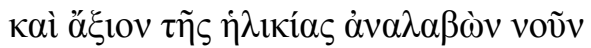

- This reminder to Eleazar, to apply his mind in a way proper to his age, reflects popular philosophical ideas - age/grey hair brings wisdom.

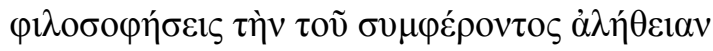

- True philosophy, according to Antiochus, knows what is beneficial - vs Eleazar's "empty notions".

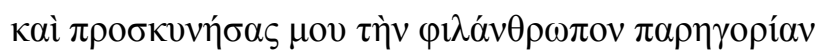

- "Respecting": literally, "worshiping" or "prostrating yourself before ..."

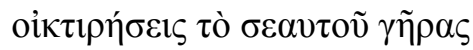

- In popular philosophy, old age is seen as bringing - besides wisdom - also weakness/frailty.

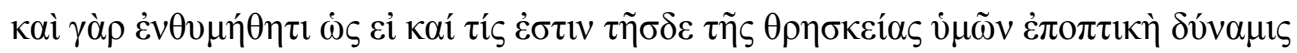
- The king is relativising the Jewish concept of God. This, of course, is a fine 
rhetorical strategy - to assume your opponent's point of view for argument's sake, only to draw a conclusion that suits your point of view better than his. ${ }^{5}$

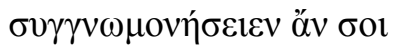

- Note the irony: Antiochus will surely not pardon any transgression of his rules.

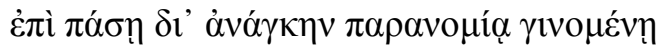

- Antiochus subtly admits that he intends using force. His command to his soldiers in

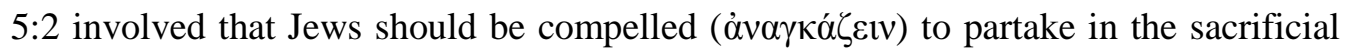
meal by eating pork. Furthermore, the suggestion that pardon may be expected for any transgression "happening" - not "done" - under compulsion, implies a lesser degree of guilt being incurred by the transgressor - another rhetorical strategy of the king.

\section{Schematic presentation of the discourse structure}

a - "kind" advice: comply and escape punishment

b - I respect your years

c - you don't seem to be a philosopher

$\mathrm{d}$ - upholding Jewish religion

e - why scorn a gift of nature?

f - foolish to refrain from blameless pleasures

e' - wrong to repulse gifts of nature

f' - even more foolish to treat me with contempt due to false ideas

a' - at risk of punishment

c' - won't you wake up from your deluded philosophy?

f' - won't you stop your foolish reasoning?

f' - won't you start thinking like a man of your age

$c^{\prime}$ - and pursue the philosophy of what is beneficial?

a' - by bowing respectfully to my kind advice

b' - respect your own years

d' - if there be some power watching over your religious observance

5 A classic example of this rhetorical strategy can be seen in the agon scene in Sophocles' Electra, where Electra reminds Clytaemnestra that she would be the first to die, if the rule of retributive justice were to be applied. 
a' - that power would surely pardon transgressions committed under compulsion

\section{Summary of themes constituting the discourse structure}

a/a' - any opposing authority would yield to Antiochus' force/power

$\mathrm{b} / \mathrm{b}$ ' - Eleazar's age is respected

c/c' - opposing philosophies: deluded $v s$ pragmatic

d/d' - Jewish religion inferior; Antiochus does not subscribe to their beliefs

e/e' - accept nature's good gifts

$\mathrm{f} / \mathrm{f}^{\prime}$ - foolishness

\section{Interpretation}

The author of IV Maccabees portrays Antiochus as a skilful orator, but surely not as one representing a logically consistent philosophical position/argument. (This implies, of course, that the author would know a skilful orator when he saw one, and would know a good philosopher when he saw one. ${ }^{6}$ The king's entire address to Eleazar could be summarised as follows: "Here is some good advice; you will disregard it at your own peril." Thus Antiochus' kindly words merely serve to disguise a stern threat of severe punishment for non-compliance with his demands.

\section{Eleazar's response}

Not unlike the agon scenes of classical tragedy, Antiochus' speech is answered by a set speech in which his opponent, Eleazar, touches upon all the main themes he has addressed ( $a, b, c, d, e$, and $f$ ). Eleazar's reply opens with a note of genuine politeness, as he first asks permission to speak. This stands in sharp contrast to the fake politeness of Antiochus' opening words (5:5-6). Then he takes on the challenge set by the king, and delivers a public address $(\delta \eta \mu \eta \gamma o \rho \varepsilon \tilde{v})$ in philosophical style $(>c)$.

He states unequivocally that for him, there is no compulsion greater than the

6 DeSilva (2007:101-105) presents a detailed characterisation of this anonymous author, as one thoroughly versed in Greek culture, language, literature, rhetoric, and ethical philosophy, but utilising all of this "to promote continued adherence to the distinctive way of life practiced by the Jews for centuries before the rise of Hellenism". 
conviction that he lives according to a divine law $(>d)$ that needs to be obeyed meticulously $\left(>a / a^{\prime}\right)$. Therefore there is no difference between smaller and greater transgressions - the law is to be respected in its entirety.

"Our philosophy", he tells Antiochus, "is not to be scoffed at" $(>c / c$ ') "as if it were foolish/unreasonable to live by it" $(>f)$. He continues by claiming that the Torah

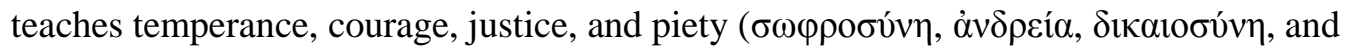

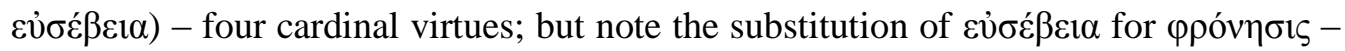

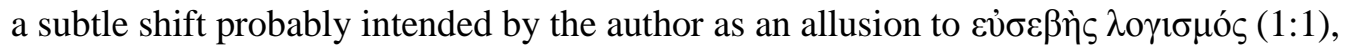

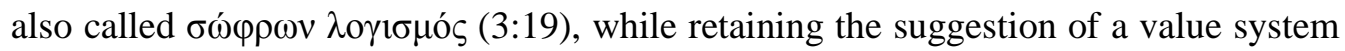
shared by the Greek oppressor and the Jewish people. The implications are important for our understanding of the core issues of this debate: Eleazar is not claiming that the Jewish philosophy is different from and superior to the Greek, but that faithful observance of the Torah teaches all the same virtues, and more - the piety that guides man's rational faculty toward a truly wise and religious life. Eleazar is teaching Antiochus here, using the Greek system but amending it to include the notion of religious piety. ${ }^{7}$

His next point answers the king's accusation that Jewish religious observance is in conflict with nature $(>e)$. "As we believe that the law is of divine origin", he retorts, "we know: the Creator ... showed us sympathy, giving us a law in accordance with

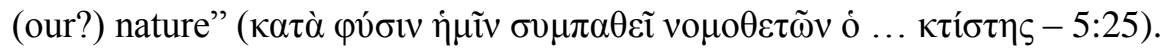

Only now - in 5:27-29 - does Eleazar confront Antiochus directly, stating unequivocally that he will not comply, even if tortured ( $\left.>a / a^{\prime}\right)$. Surely he is not so old $(>b)$ and cowardly (lacking $\alpha \dot{\alpha} \delta \rho \varepsilon i ́ \alpha)$ as "not to rejuvenate my reasoning powers in

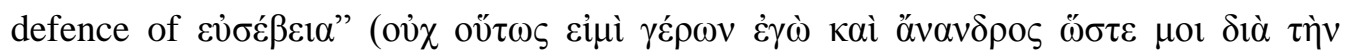

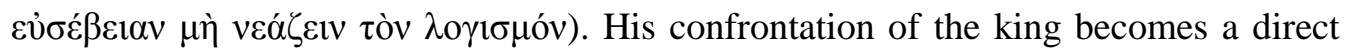
challenge: "Bring your instruments of torture; heat up the fire ..." $(>a)$. "I will not pity

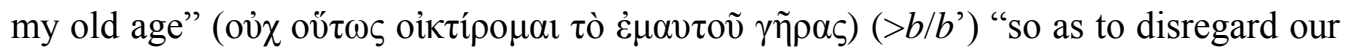

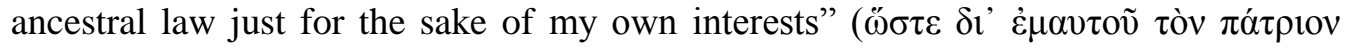

7 Van Henten (1997:277) discusses these virtues in the context of the debate, but misses this point, stating only: "This implies that ... Jewish philosophy measures up to philosophies which were highly esteemed in the intellectual framework of the tyrant." 
$\kappa \alpha \tau \alpha \lambda \tilde{v} \sigma \alpha \mathrm{l}$ vó $\mathrm{ov})(>d)$.

\section{Outcome of the agon}

In the end, the king's victory becomes the king's defeat. His insincere philosophical arguments cannot hide the threats of physical violence; and once exposed by Eleazar, he has no options left other than to do as he has threatened - to have Eleazar tortured and killed. His actions show the inadequacy of his philosophical position. (Cf. DeSilva 2013:67: "Antiochus is impelled to act by his own passions, which is a bitter indictment of his fitness to rule". Quoting IV Macc 8:2 about Antiochus' "exceedingly violent passion", DeSilva comments: "[T]his anger com[es] from his defeat by Eleazar, his frustration at his own inability to coerce an elderly man to obey”.)

Eleazar, on the other hand, is portrayed in an entirely positive light in this debate. This picture of the martyr is supported by two explicit comments from the author; one at the conclusion of the speech (

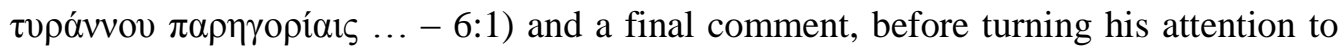
the other martyrs: "For only the wise and courageous is lord of the emotions" ( $\mu$ óvo

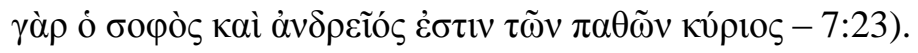

\section{CONCLUSION}

In the final analysis, the reader needs to keep in mind that every impression, observation or conclusion that has been expressed in this paper relates not to a set of objective "facts", but to the textual world of IV Maccabees; to the conceptual world that the author presents to our minds by means of the text.

Eleazar's philosophy, as presented by the author of IV Maccabees, is not distinctly Jewish - it is informed by (Hellenistic) Greek philosophy and skilled in the rhetorical means by which this philosophy is practised. His philosophy is, however - in sharp contrast to that of Antiochus IV - distinctly honest, distinctly devout, and distinctly consistent.

Evidently, the anonymous author of IV Maccabees was fully competent in 
Hellenistic philosophical rhetoric; but the book was not intended to be a philosophical discourse in its entirety. It is mainly narrative in character; but this does not mean that it is a mere retelling of the stories of the Maccabean martyrs. The portrayal of these persons forms the central focus; and this portrayal is done mainly by presenting them involved in dialogue with Antiochus or his officials. In the case of Eleazar, the dialogue between him and Antiochus - the main focus of this paper - is presented as an agon, a contest; but this contest is not so much the spectacular, brutal clash that physically destroys this Jewish martyr in the end, as it is the philosophical/rhetorical contest in which the martyr is portrayed as victorious, since he is shown confronting and beating the Greek oppressor at his own game.

\section{BIBLIOGRAPHY}

Anderson, H 1985. 4 Maccabees (First Century A.D.), in Charlesworth 1985/2:531-564.

Charlesworth, J H (ed.) 1985. The Old Testament Pseudepigrapha. Garden City: Doubleday.

Craven, T 2014. Martyred mother with seven sons (4 Macc): Apocrypha. Available:

http://jwa.org/encyclopedia/article/martyred-mother-with-seven-sons-4macc-apocrypha [Accessed 2014/08/08].

DeSilva, D A 2006. 4 Maccabees: Introduction and commentary on the Greek text in codex Sinaiticus. Leiden: Brill.

2007. Using the master's tools to shore up another's house: A postcolonial analysis of 4 Maccabees, Journal of Biblical Literature 126/:99-127.

2013. The human ideal, the problem of evil, and moral responsibility in 4 Maccabees, Bulletin for Biblical Research 23/1:57-77.

Klauck, H-J 1994. Hellenistische Rhetorik im Diasporajudentum. Das Exordium des vierten Makkabäerbuchs, in Klauck (ed.) 1994:99-113.

Klauck, H-J (ed.) 1994. Alte Welt und neue Glaube: Beiträge zur Religionsgeschichte, Forschungsgeschichte und Theologie des Neuen Testaments. NTOA 29. Freiburg/Göttingen.

Newsom, C A \& Ringe, S H (eds) 1998. Women's Bible commentary. Kentucky: Westminster John Knox.

Van Henten, J W 1997. The Maccabean martyrs as saviours of the Jewish people: A study of 2 and 4 Maccabees. Leiden: Brill. 2008. Review of 4 Maccabees: Introduction and commentary on the Greek text in codex Sinaiticus by D A DeSilva, Journal for the Study of Judaism 39:399-400.

Young, R D 1998. 4 Maccabees, in Newsom and Ringe 1998:330-334. 